by the science of metals. At the end of the third year, the student takes Part I of the Final Honour Examination, which consists of the normal written papers and practical examinations in inorganic and physical chemistry, together with written papers and practical examinations in the science of metals. The passing of this examination enables the student to take the B.A. degree, but to obtain classified honours a fourth year must be spent at research work on an approved metallurgical subject.

The four-years course outlined above should be of high scientific value. It brings the student into contact with all three branchos of chemistry, two of which are studied to an advanced level, together with some branches of physies and of the newer sciences of the solid state. It is also directly related to the industrial practices of motallurgy. The inorganic chemistry should enable the graduate to understand the principles underlying the extraction and smelting of metals. The physical chemistry should make him familiar with the principles of chemical equilibrium and reaction kinetics, and so enable him to understand processes such as slag/metal equilibria, fuel/gas reactions, etc. Finally, the metal-science part of the course should teach the student much about the stmucture and properties of metals and alloys, and their relation to processes involved in industrial practice. It is hoped that a graduate trained on these lines will be a useful man (or woman) in many ways. If he enters industry, he will, of course, have to learn the technology of his subject. This is the case with graduates in physics or chemistry whose university training is in pure science, and it is hoped that metallurgical industry will find many uses for men trained in the sciences of chemistry and of metisls.

The Department of Metallurgy at Oxford also offers facilitios for postgraduate research work for the B.Sc. and D.Phil. degrees. The laboratory is well equipped for thermal analysis, microscopical metallography, X-ray metallography, and electron microscopy. The staff at present consists of one reader, Dr. W. Hume-Rothery, two lecturers, Dr. J. W. Christian and Dr. J. W. Martin, and one graduate assistant, Dr. A. Hellawell.

\title{
OBITUARIES
}

Prof. Frank Horton, F.R.S.

Prof. Frank Horton, emeritus professor of physics in the University of London, died on October 31 , at his home in Cambridge. He was the eldest son of Albert Horton, of Olton, Warwickshire, and was born on August 20,1878; his mother's maiden name was Kate Louisa Carley.

Horton began his academic career at King Edward VI Grammar School, Birmingham, and even at that early date began to devise and carry out experiments in physics. Leaving school, he proceeded to Mason College (later the University of), Birmingham. Here he obtained first-class honours degrees in both physics and chemistry, and then began a series of researches on the elastic properties of wires and quartz. In this work, directed by Prof. Poynting, use was made of a variation of the 'method of coincidences' for determining a periodic time. An account of this work appeared in the Philosophical Transactions of the Royal Society and earned for Horton his first doctorate at the University of London in 1903.

In 1901 Horton went to St. John's College, Cambridge, as an 1851 Exhibition Research Scholar. For his research work with Sir J. J. Thomson, during which Horton became interested in the production of high vacua, he was elected a Mackinnon Research Student of the Royal Society in 1903. Among their other activities, Thomson and Horton found time to edit the important series of Physics Monographs, published by Longmans, Green and Co., Ltd. In 1905 Horton was made a Fellow of St. John's and during 1905-13 was a lecturer at the Cavendish Laboratory.

At the age of thirty-five, Horton was elected to the chair of physies at the Royal Holloway College, Englefield Green, Surrey. The earlier occupants of this chair were Prof. H. L. Callendar, Prof. W. Cassie and Prof. P. V. Bevan. Prof. Horton's work at Cambridge had equipped him with the tools necessary to carry on fundamental work on electronics and soft X-rays. During the First World War he investigated, among other things, the effect of helium on the stability of electron emission from heated filaments.

In 1911 Frank Horton married Miss Vera Fulton, of New Zealand, where the marriage ceremony took place, and his daughter, Ngaire, now Mrs. Bajko, survives him. She lives in Now Zealand and has a son, Michael.

In 1923 Prof. Horton was elected a Fellow of the Royal Society and two years later, as a member of the Senate of the University of London, found himself in the thick of many controversies then current in academic circles; he was always a champion of the rights of university teachers. As chairman of many university bodies he was meticulous in the dispatch of business. He was dean of the Faculty of Science during 1930-34 and in 1932 was elected a member of the Court of the University. In September 1939 he became vice-chancellor, a post which he held until 1945 - such was the measure of the confidence his colleagues had in him as an administrator of the highest order. Earlier in 1939 he married one of his former students and a co-research worker, Miss Ann Catherine Davies, who was staff lecturer in physics at the Royal Holloway College during 1922-29, when she left to take up a post at Newnham College, Cambridge, where she is now vice-principal. Mrs. Horton is an active member of the Council of Royal Holloway College, and this enabled Prof. Horton to keep in contact with the scene of his former labours when he retired in 1946 from his chair of physics and went to live in Cambridge.

His successor, Prof. S. Tolansky, found the laboratories in the department which Horton had helped to design in the middle 'twenties well equipped to meet the neods of present-day workers in physics. These laboratories form part of a block which houses both the Botany and Physics Departments of the College, and when they were opened in 1928, Prof. Horton paid high tribute to Dr. Margaret Benson, head of the Botany Department during 1893-1922 (she occupied the chair during 1912-22), for it was 
she who had conceived the idea for the erection of a new building and had done so much to bring it to fruition.

Horton was a physicist gifted with remarkable experimental skill, and those who worked with him were inspired by the dextrous and confident manner in which he would handle and adjust highly sensitive instruments. He was never more pleased than when he could watch an undergraduate carrying out an experiment with meticulous care.

The funeral service was held on November 2 at St. John's College Chapel, and the large attendance on that occasion testified to the high esteem in which Prof. Frank Horton was held.

$$
\text { C. J. Sмrтн }
$$

\section{Dr. Paul D. Merica}

We regret to announce the death of Dr. Paul D. Merica, of the International Nickel Co. of Canada, in New York on October 20. Dr. Merica was born in Warsaw, Indiana, in 1889. He attended $\mathrm{De}$ Pauw University during 1904-7, graduated from the University of Wisconsin in the following year, and received his Ph.D. from the University of Berlin in
1914. During 1914-19 he was associated with the metallurgical division of the U.S. Bureau of Standards in Washington. Dr. Merica carried out a number of researches on duralumin and other aluminium alloys and developed his theory of the precipitation hardening of metals and alloys.

Dr. Merica first became associated with the International Nickel Co. in 1919, becoming director of research and later assistant manager of the Development and Research Department. He was made president of the company in May 1952, retiring from the last post in April 1954.

For his contribution in the field of metallurgy and outstanding leadership in physical metallurgy, Dr. Merica, who was a member of the U.S. National Academy of Sciences, was awarded the James Douglas Medal in 1929, the John Fritz Medal in 1938, the Institute of Motals Medal in 1941, the Franklin Institute Medal in 1942, and American Society for Metals Gold Medal in 1951. Dr. Merica was an honorary member of the American Institute of Mining and Metallurgical Engineers, of which he was a former vice-president and director, as well as of the American Society for Metals.

\section{NEWS and VIEWS}

Metallurgy at Oxford :

Prof. W. Hume-Rothery, O.B.E., F.R.S.

THE development of metallurgical science at Oxford has been continuously associated with the work of Dr. Hume-Rothery, and his many friends will warmly welcome his appointment as the first Isaac Wolfson professor of metallurgy (see p. 1319 of this issue). Dr. Hume-Rothery was at the beginning of an army career when a serious illness left him totally deaf. Despite this affliction, he obtained a first in chemistry at Oxford and a Ph.D. at the Imperial College of Science and Technology, London, before returning to Oxford to found the research school in alloy theory, which soon became internationally famous. He was elected a Fellow of the Royal Society in 1937, and he was Warren Research Fellow of the Society during 1932-55, when he became the first holder of the George Kelley readership. Post-war developments in the teaching of metallurgy are largely the result of his enthusiasm and hard work. Dr. Hume-Rothery's early experimental work led to our present understanding of many of the factors governing the form of metal. lurgical equilibrium diagrams. Perhaps the bestknown results are the discovery of the 'electron compounds' and the enunciation of the famous size. factor rule. During the War, his group worked on complex aluminium alloys, and since then his main interest has been in high melting point alloys of the transition metals. He is equally distinguished as the author of five text-books, and his very successful expositions of modern theories have been translated into many languages. Dr. Hume-Rothery was awarded the platinum medal of the Institute of Metals in 1949, and has also received awards from scientific societies in the United. States, the Netherlands and Italy.

Reports of the Nationalized Industries in Britain

IN a debate in the House of Commons on November 26, which took note of the annual reports and statements of accounts of the Gas and Electricity Industries, the Paymaster-General, Mr. R. Maudling, as representing the Minister of Power, said that the surplus of $£ 3.8$ million shown in the latest report of the gas industry is due to the increased efficiency of the industry. The number of units in the industry have been reduced from 1,050 at vesting day to 611 ; the thermal efficiency has been increased to 77.8 per cent, and although the cost of coal and manual labour has risen by 65 per cent since 1950, the price of gas, which represents two-thirds of the industry's sales, has risen by only 47 per cent, and that of coke and by-products by 78 per cent. Mr. Maudling referred to the increasing competition of electricity and the increasing scarcity and cost of good-quality coking coal. The industry is accordingly seeking to exploit lower-grade cheaper coal, and much work is being done on the Lurgi process of complete gasification and on the hydrogenation of oil and coal. The Lurgi process, however, yields gas of low calorific value, and it has not yet been fully proved with grades of coal available in Britain; but if the work of the North Western Board on hydrogenation is successful, it should be possible to produce gas of good quality from a wide range of comparatively low-quality, lowpriced coal. Both the Lurgi process and hydrogenation have the advantage of producing no coke, of which there is at present a surplus. The industry is also examining the use of surplus products from the oil refineries, as well as of imported oil, and, besides prospecting for natural gas in Britain, is studying the import of liquefied methane, the use of coke-oven gas and, in co-operation with the National Coal Board, the use of methane from coal pits, as well as both the long-distance transmission and the storage of gas.

Turning to the electricity industry, Mr. Maudling said that total sales last year increased by 6.7 per cent, and sales to farms by 18 per cent, while the average price of electricity sold by the Central Electricity Board increased by 4.7 per cent. Since 1948 the 